\title{
POVO BRASILEIRO NOS LIVROS DIDÁTICOS DE HISTÓRIA REPUBLICANOS: 1889-1950*
}

\author{
Kênia Hilda Moreira** \\ keniamoreira@ufgd.edu.br
}

\begin{abstract}
Resumo: O presente artigo discute as concepções de povo brasileiro em seis livros didáticos de História do Brasil utilizados entre 1889 e 1950. O texto está dividido em três partes: 1. Questões iniciais sobre povo, miscigenação e embranquecimento; 2. Apresentação da concepção de povo brasileiro em cada autor e seus respectivos livros didáticos; e 3. Observações gerais, em que destacamos nos livros didáticos analisados o gradativo reconhecimento das três raças como formadoras do povo brasileiro e a mudança da interpretação acerca da miscigenação, que passa de algo nocivo a positivo e parte integrante da ideologia do Estado.
\end{abstract}

Palavras-chave: Povo, República, Livros didáticos de História do Brasil.

Considerando que "república" significa governo do povo", objetivamos discutir neste artigo as concepções de povo que perpassaram seis livros didáticos de História do Brasil produzidos e utilizados no contexto escolar brasileiro entre 1889, marco inicial da República no Brasil, e 1950, último ano de vigência da Lei Orgânica do Ensino Secundário, de 1942, e dos respectivos programas de ensino elaborados em âmbito federal pelo Ministério da Educação e Saúde Pública (MESP).

Os livros selecionados para a presente análise foram:

- Lições de História do Brasil de Joaquim Manuel de Macedo (Rio de Janeiro: Editora Garnier em 1907) [1.ed. 1865?]. Título indicado nos programas do Colégio Pedro II até 1882. Reeditado até 1928.

\footnotetext{
* Uma primeira versão dessa pesquisa foi apresentada no V Simpósio Internacional de História Culturas e Identidades - ANPUH/GO, realizado na UFG em 2011.

** Professora da Faculdade de Educação da Universidade Federal da Grande Dourados/MS.
} 
- História do Brasil curso superior de João Ribeiro. (Rio de Janeiro: Francisco Alves: 1928) [1. ed. 1900]. Indicado nos programas do Colégio Pedro II até 1915.

- História do Brasil para o ensino secundário de Rocha Pombo. (São Paulo: Editora Melhoramentos, 1925). [1. ed. 1918]. Reeditado até 1967.

- Epítome de História do Brasil de Jonathas Serrano. (Rio de Janeiro: Editora F. Briguiet \& Cia, 1941) [1. ed. 1933]. Título lançado após a reforma Francisco Campos e serviu de referência para a disciplina História da América e do Brasil.

- História do Brasil de Basílio de Magalhães. 2a série dos cursos clássico e científico. (Rio de Janeiro: Francisco Alves, 1958).²

- História do Brasil de Joaquim Silva. $3^{\text {a }}$ série ginasial. (São Paulo: Editora Companhia Nacional, 1943). De acordo com o programa de 1943.

\section{QUESTÕES INICIAIS}

Quem integrava o povo brasileiro nos diferentes contextos sócio-históricos? No final do século XIX e início do XX vigoravam as teorias raciais fundamentadas num modelo racionalista-evolucionista. Nesse modelo a mistura racial era explicada como prejudicial ao progresso da nação, conforme podemos ler nos diferentes "intérpretes do Brasil".

Para Sílvio Romero em O Evolucionismo e o positivismo no Brasil: "A distinção e desigualdade das raças humanas é um fato primordial e irredutível, que todas as cegueiras e todos os sofismas dos interessados não têm forças de apagar. É uma formação que vai entroncar-se na biologia e que só ela pode modificar" (ROMERO, 1894, p. 37). Sobre as raças existentes no Brasil, o autor afirmou em Mestiçagem e literatura nacional que

O tipo branco irá tomando a preponderância, até mostrar-se puro e belo como no velho mundo. Será quando já estiver de todo aclimatado no continente. Dois fatos contribuíram largamente para tal resultado: de um lado a extinção do tráfico africano e o desaparecimento constante dos índios, de outro a imigração europeia. (ROMERO, 1978, p. 55).

Ao teorizarem a formação do povo e a organização social, os intelectuais mais diversos concluíam pela nocividade da miscigenação e ao mesmo 
tempo anunciavam o pretenso embranquecimento e europeização das populações. ${ }^{3} \mathrm{~A}$ imigração branca aparecia como estabilizadora dos intercâmbios étnicos, e consequente diminuição do "sangue inferior".

Uma visão contrária nos remete a Karl Friedrich Philip von Martius que, em argumentos originais, postulava em 1840 que o tipo "brasileiro" deveria se originar da fusão racial.

São, porém estes elementos de natureza muito diversa, tendo para a formação do homem convergido de um modo particular três raças, a saber: a de cor cobre ou americana, a branca ou caucasiana, e enfim a preta ou etiópica. Do encontro, da mescla das relações mútuas e mudanças dessas três raças, formou-se a atual população, cuja história por isso mesmo tem um cunho muito particular. (MARTIUS, 1982, p. 87).

Quais mudanças e quais permanências em torno da concepção de povo brasileiro são observadas nos livros didáticos de História do Brasil em circulação a partir da proclamação da República até a metade do século XX?

CONCEPÇõES DE “POVO BRASILEIRO” NOS LIVROS DIDÁTICOS DE HISTÓRIA DO BRASIL

Para efeito didático, neste tópico apresentaremos os autores individualmente.

\section{Lições de História do Brasil de Joaquim Manuel de Macedo}

Ao mencionar Lições de História do Brasil de Macedo, José Honório Rodrigues (1988) critica a ausência de uma análise das condições sociais e do povo nesse livro didático.

Para Macedo os conhecimentos históricos e os geográficos ao se entrecruzarem possibilitariam "a identificação de um país e a identidade de um povo". Ou seja, ofereciam "elementos para conhecer o território brasileiro, um continente abençoado e estável, que continha uma sociedade com tendências a fragmentação". (MACEDO, 1907, p. 71). É com essa perspectiva que Macedo apresenta separadamente, o índio e o negro em Lições de História do Brasil.

Macedo define os indígenas como "gentios" e os apresenta ao descrever o território "descoberto". A narrativa inicia-se pelos aspectos naturais e geográficos: vegetação, zoologia, ornitologia, riqueza do solo e hidrografia, e culmina com a exaltação da natureza das regiões recém-descobertas: "aos olhos dos descobridores e conquistadores do Brasil o que se apresentava menos digno de admiração, mais pequeno, mais mesquinho foi o homem que habitava, e senhoreava esta vária região" (MACEDO, 1907, p. 38). 
A abordagem do autor em relação aos indígenas guiava-se pelo olhar etnológico superficial, assinalando curiosidades do cotidiano e as diferenças com o homem civilizado.

$\mathrm{O}$ autor narra os indígenas como pertencente a um povo na sua infância, rudes e selvagens, alheios à civilização. $\mathrm{O}$ tom se ameniza quando se detém à concepção de família: "embora muito limitado", "o gentio do Brasil tinha laços de família". Porém, ao abordar as relações sociais nota a falta de governo centralizador e de religião, elementos essenciais de uma civilização. De outra forma, o autor valida o estereótipo do "índio sem fé, sem lei e sem rei" próprio de um senso comum que remontava a Gândavo no século XVI.

O autor não apresenta os indígenas como elemento do povo brasileiro. A questão é silenciada. Isso se deve ao fato de Joaquim Manuel de Macedo referir-se aos indígenas como algo do passado e reproduzir uma visão centrada na descrição dos primeiros cronistas (GASPARELLO, 2002).

No que diz respeito aos negros, a principal referência aos negros escravos enquanto agentes históricos constam na lição "Destruição dos Palmares - Guerras civis dos Mascates, em Pernambuco; e dos Emboabas, em Minas, 1687-1714". O episódio de Palmares é narrado como parte dos atentados contra a monarquia portuguesa e da administração colonial. $\mathrm{O}$ autor alude os quilombolas como desertores, criminosos e ameaçadores.

Embora se perceba a coragem dos quilombolas na narrativa apresentada pelo autor, o que se destaca é a valentia dos paulistas e o perigo do quilombo.

Uma narrativa que contemplasse o negro como elemento formador do povo brasileiro estava fora de perspectiva, mesmo em textos não didáticos de Joaquim Manuel de Macedo, como em As vítimas-algozes, quadros da escravidão $0^{4}$.

\section{História do Brasil: curso superior de João Ribeiro}

Para João Ribeiro os elementos constitutivos da nacionalidade seriam o branco, o negro e o índio, e os agentes formadores, o jesuíta, o criador de gado e o paulista bandeirante.

Em busca da contribuição específica das etnias afirmava que os brancos trasladados para a colônia traziam os "vícios da decadência" de Portugal; o negro, por seu lado, fora o verdadeiro elemento econômico; e o índio pouco teria contribuído para o desenvolvimento econômico. Em outras palavras, o branco é "ávido e atroz", o negro, "servil", e o índio, "altivo e indolente", sendo 
esses "os três elementos donde vai sair a nacionalidade futura. Mas a agitação étnica é toda subterrânea e está repartida por todo o subsolo, guardando a futura erupção" (RIBEIRO, 1928, p. 110).

A "fusão das raças branca, negra e vermelha" gerou "vários tipos de cruzamentos (mameluco, mulato, cafuzo), branco-índio, branco-negro, índio-negro" ocorrendo o mesmo fenômeno nos costumes e na linguagem. Pessimista, concluía: "A sociedade mesclada, incapaz de unir-se, logo se enfraquece e se corrompe" (RIBEIRO, 1928, p. 42) ${ }^{5}$.

Em João Ribeiro a nacionalidade brasileira será representada pela "raça nacional mameluca", para ele, um dos elementos capazes de conferir "homogeneidade integradora" a nação. A cultura nacional seria a expressão da "psicologia" dessa "raça nacional" e, ainda que isso possa parecer contraditório, já que postulava a incapacidade de união da sociedade mesclada, escreve Hansen (2000, p. 89-90), "não há aí qualquer contradição, pelo menos do ponto de vista da argumentação do autor, pois essa cultura era caracterizada pela desmoralização".

O autor enfocava o despreparo do mameluco para o autogoverno, porém, acreditava que a articulação entre raça nacional e cultura da desmoralização seria passível de solução.

O único remédio para esses povos é o mesmo da antiga colonização, o povoamento contínuo e a imigração europeia (ainda que errada, como nos tempos de Nóbrega) que trabalha nos ofícios e arroteia os campos, inocula a vida e coordena essas desordens e, como dizia Tomé de Souza, não cobra do tesouro (RIBEIRO, 1928, p. 286).

\section{História do Brasil para o ensino secundário de Rocha Pombo}

Para Rocha Pombo a "legenda do Caramuru" e a "legenda de João Ramalho", serviam para evidenciar as relações entre portugueses e índios, as quais teriam contribuído para o domínio do território.

No mais, se refere ao "abastardamento geral das três raças"

Dizemos - abastardamento - em vez de fusão regular e legítima, porque, de fato, o que se fez no Brasil não foi mais que um amálgama dos elementos mais degradados das três raças: - o índio, submetido pela força; o africano, rebaixado até a animalidade; - e o europeu, que vinha dos presídios, ou que se transportava para a América tangido de cobiça. (ROCHA POMBO, 1925, p. 66). 
Rocha Pombo descreve o caráter do povo brasileiro atento às discussões e polêmicas quanto a formação da nacionalidade, conforme Bittencourt (1998, p. 195), ao afirmar que as marcas da escravidão estavam presentes nos primeiros anos da República e existiam dois caminhos interpretativos: "enfrentar esse passado e procurar formas de encaminhamento sobre os problemas sociais decorrentes desse processo histórico ou omitir e deixar silenciado seu passado".

Em História do Brasil para o ensino secundário, os africanos comparecem como tema no capítulo dedicado aos "protestos da raça negra" no qual se explica os quilombos e a abolição: "o africano, cuja natureza moral parecia como que estremecer e agitar-se nas vicissitudes da escravidão, deu no Brasil, como em quase toda a América, frequentes provas do grande vigor humano que trazia lá das suas misérias do continente negro" (ROCHA POMBO, 1925, p.156).

Esse vigor referia-se às manifestações de liberdade: "Desde que chegava ao seu exílio e se via em presença de uma raça superior, a emancipação era o sonho torturado do negro", aspiravam "a felicidade que via gozada pelo branco" (ROCHA POMBO, 1925, p. 157).

Dois capítulos são dedicados aos "povos que habitavam o Brasil". Na visão do autor, os "indígenas brasileiros" tiveram a sorte de descender da raça superior inca. Ao estabelecer essa filiação, segundo Bittencourt (1990), o autor procurava "difundir, pelo ensino os ideais de confraternização entre as nações americanas". Ainda segundo Bittencourt "o elemento indígena não era tido como obstáculo à marcha do progresso, mas visto como um agente na colonização pelo trabalho e, contraditoriamente reconhecia a sua luta de resistência frente ao branco" (Idem, p. 86-87).

Rocha Pombo descreveu em detalhes os modos e costumes dos índios tupi. Ele narra uma sociedade indígena com elementos básicos de organização e disciplina, além dos hábitos alimentares e de higiene. Segundo Ribeiro (2004, p.73), Rocha Pombo "enxergava como virtudes, algo a se admirar, esse modo de viver dos índios" e "construiu uma figura indígena simpática e prestimosa".

Sobre a construção da identidade do povo brasileiro encaminhada pelo autor, Sevcenko (1999, p. 111) considera que ao contrário de outros intelectuais que estabeleciam o tipo nacional com base na conformação étnica, Rocha Pombo via na possessão de "uma certa história em comum" as origens da nacionalidade. 


\section{Epítome de História do Brasil de Jonathas Serrano}

Quanto à contribuição das etnias para a formação do Brasil, Jonathas Serrano expõe o tema nos capítulos "O elemento indígena" e "O elemento negro".

O autor explica didaticamente as "tribos selvagens", o "estado de civilização do indígena brasileiro", a "catequese" e a "importância do elemento indígena"'.

Seria engano julgar dos costumes e das qualidades dos nossos silvícolas pelas descrições românticas de Alencar ou Gonçalves Dias. O tio de Peri, no Guarani, o de Iracema, o do guerreiro do I-Juca-Pirama são fantasias literárias.

Mas é inegável a coragem dos indígenas, provada em várias ocasiões em nossa história, quer combatessem conosco, ou contra nós. Figuram alguns em nossa galeria de heróis: Araribóia, Piragiba e Poti (SERRANO, 1941, p. 85-86).

A influência exercida "pelos nossos silvícolas" está "na própria língua portuguesa falada no Brasil" e "também no domínio do folclore".

A “contribuição do elemento negro" é explicada no contexto do Segundo Reinado, quando o autor trata da Abolição. É quando dedica um capítulo sucinto ao quilombo dos Palmares sem introduzir explicações inovadoras, quando comparado aos demais autores didáticos. Nota-se no capítulo uma tendência na literatura didática preocupada em assinalar as mazelas da escravidão e os sofrimentos do negro.

Do século XVI em diante, filas e filas de negros escravizados, de pesada cadeia ao pescoço e presos uns aos outros para não fugirem, seguiam rumo da costa, marcados a ferro e brasa e sob o chicote dos Tumbeiros. Eram comprados, em geral, a troco de miçangas, de pano da Costa riscado, de cachaça ou de objetos de aço. Eram levados para os presídios (Caconda, Ambaca) e depois embarcados nos principais portos (S. Paulo de Luanda, S. Filipe de Benguela). Atirados no porão de imundos navios, só de vez em quando podiam subir à coberta para dançar e respirar um pouco de ar puro, que lhes conservasse a vida. Dizimava-os a bexiga, o sarampo, os maus tratos e a fome. Muitos preferiam a morte, jogando-se ao mar. A alguns consumia lentamente a saudade da terra, o Banzo. (SERRANO, 1941, p. 158-159. Grifos do autor). 
Ao contrário dos indígenas, considerados "rebeldes e avessos ao trabalho pesado" e tendo a proteção dos jesuítas, "os negros sem proteção legal, eram tratados como animais pelo feitor, sempre disposto a punir de chicote, ou mais cruelmente ainda, qualquer falta cometida. Viviam nas senzalas, amontoados sem higiene nem conforto algum". (SERRANO, 1941, p. 159).

$\mathrm{Na}$ escrita do autor era como se a sociedade contemporânea reconhecesse os erros do passado e idealizasse o presente e o futuro como tempos melhores. Todavia, amenizou a narrativa ao escrever que no Brasil os negros eram "mais feliz ou menos desgraçados que noutros países, inclusive as colônias norte-americanas. Muitas vezes o escravo ou escrava se tornava querido dos senhores e sobretudo das crianças" (SERRANO, 1941, p. 159-161).

Para Resnik (1992) essa "positivação" traduz um movimento de valorização do trabalho, difundido nos livros didáticos no período estadonovista.

Quanto à "contribuição do negro em nosso meio", o autor assinala uma grande e natural influência: "A afetividade da Mãe Preta é um fato comovedor de nossa história doméstica e social” (RESNIK, 1992, p. 163). Como que ilustrando tal assertiva o livro reproduz um quadro de Jean Baptiste Debret - D. Pedro II, ainda na infância, repousa no colo de uma mucama.

Dentre as "qualidades boas ou menos felizes que herdamos dos negros” constava:

As crendices, as superstições, o amor da música e da dança, certa "negligencia criola", resignação heroica na miséria, concepção fatalista e leviana da vida, imprevidência unida ao trabalho

$[\ldots]$

São de origem africana o vatapá, os angus, a canjica, a pamonha, as moquecas e outros quitutes; o cateretê, o jongo, a congada e a música de chocalhos e guizos; o transporte em cadeirinha (banguê) ou rede (tipóia). O vocabulário sofreu também a influência do elemento negro: quilombo, quitanda, mandinga e infinitos outros exemplos. (RESNIK, 1992, p. 163; 164-165).

De fato o tema da influência das "três raças" se fortaleceu na Era Vargas quando o discurso da construção da nação pela "união das raças" é contraposto ao "regionalismo desagregador".

\section{História do Brasil de Basílio de Magalhães}

No capítulo sobre a formação étnica do povo brasileiro, em conformidade com o programa oficial, Basílio de Magalhães considera-a produto 
da fusão entre o "Xantodérmico, dono de toda a vasta região e ocupando-a sem solução de continuidade", o "leucodérmico, representado pelo português descobridor e colonizador" e outros europeus, e o "melanodérmico, aqui introduzido em avultada quantidade".

A formação da nossa nacionalidade, resultante do cruzamento de três etnias deveras heterogêneas, caracterizou-se de maneira inexpressiva, permitindo que o nosso maior conhecedor do período colonial - o grande mestre Capistrano de Abreu - viesse a dizer que a vida social não existiu porque não havia sociedade. Esta apreciação, aparentemente paradoxal, corresponde, de fato, à realidade (MAGALHÃES, 1958, p. 211. Grifo no original).

No tópico "Primitivos brasis" Basílio de Magalhães fez constar as origens ameríndias, as classificações, o estado político, social, religioso e cultural dos indígenas brasileiros.

Quanto ao "elemento português", em poucas páginas elogiosas, define-o como sem preconceito de raça. Tal qualidade teria evitado o "enquistamento étnico, semelhante ao que constitui o mais grave problema da grande república yankee" (MAGALHÃES, 1958, p. 42).

Quanto ao "negro africano", detalha, quando comparado a outros autores didáticos, a introdução dos negros na colônia, seu estado de civilização e o quilombo dos Palmares. Por fim, aposta no "embranquecimento do nosso povo" ao longo do processo evolutivo nacional.

Quanto às contribuições do negro, escrevia que "exerceram significativa influência em todos os setores da nossa evolução" [...] "mais ainda do que o elemento indígena" [...]. "Além disso, a extrema sentimentalidade do brasileiro deve ter sido incrementada pelo farto leite da 'raça afetiva', denominação acertadamente dada por Augusto Comte à africana" (MAGALHÃES, 1958, p. 47).

Sobre a introdução dos negros africanos ressalta dois fatores que consideramos importantes, a saber: os jesuítas como contribuidores do aumento da escravidão por condenarem a escravidão indígena: "Note-se que os jesuítas que tão denodadamente defenderam a liberdade dos índios, se aproveitaram do trabalho dos pretos cativos, desde o tempo de Nóbrega". (MAGALHÃES, 1958, p. 44); e a figura do "bom senhor", como observou Resnik (1992), quando postulou que a escravidão era mais prejudicial ao branco do que ao negro escravizado. 
Fator preponderante da nossa economia até 1888, o elemento negro não deixou de concorrer para a indolência e até para a dissolução moral dos seus escravizadores. Assim, bem considerada ao seu aspecto psicológico e amplo, a escravidão moderna foi mais funesta aos brancos do que aos pretos, porquanto estes formaram para os seus descendentes livres, nas plagas edênicas do Novo-Mundo, um berço e uma civilização, como provavelmente jamais teriam nas míseras cubatas e nos adustos rincões da África (MAGALHÃES, 1958, p. 47).

Em Basílio de Magalhães a civilização brasileira constitui-se em prolongamento da civilização ibérica conforme detectou Correa Filho (1957). Prolongamento que recebeu o influxo do "novo meio, novas raças e correntes migratórias" tendentes a constituir um organismo cultural emancipado. Desse modo, éramos antes brasileiros, depois americanos, por solidariedade continental.

\section{História do Brasil de Joaquim Silva}

Sobre "a formação étnica" Joaquim Silva escrevia que nem todos os degredados enviados de Portugal para a colônia eram criminosos, ladrões ou assassinos: "Naquele tempo condenava-se ao degredo e a outras penas maiores por motivos que hoje nem constituem delitos puníveis, havendo assim, entre os degredados, gente realmente honesta e trabalhadora". Essa ressalva se justifica pela valorização da raça branca como elemento formador da nacionalidade: "segundo escreve Martius, o grande rio cujos afluentes foram o índio e o africano" (SILVA, 1943, p. 86).

Os indígenas são descritos conforme as origens e classificados em grupos principais e menores. Joaquim Silva reconhecia haver "diferenças de certos costumes entre os diversos grupos ou mesmo entre tribos do mesmo grupo", mas diz que muitos desses hábitos "eram comuns a todas elas".

Quanto às influências indígenas dizia "serem notáveis nos costumes e na língua dos brancos", poucos e esparsos, os portugueses "se deixaram dominar pelos hábitos da terra", passaram "a imitar os selvagens na rude e livre vida”. (SILVA, 1943, p. 98; 99).

Sobre "o negro" o tratamento é igualmente colonialista: "da África, terra de escravidão, era possível trazer, aos milhares, pretos que já eram escravizados por seus régulos e que, vindo para o Brasil, trocavam um cativeiro por outro, aliás, menos desumano que o sofrido na terra natal". (SILVA, 1943, p. 101).

Sobre a "influência do negro", assim como Jonathas Serrano em Epitome de História do Brasil, Joaquim Silva deduzia, baseado em "antiga 
crônica" de Antonil, ${ }^{7}$ que "os escravos são as mãos e os pés do senhor de engenho, porque sem eles, no Brasil, não é possível fazer, conservar ou aumentar a fazenda, nem ter engenho corrente". Além do aporte econômico, a influência do negro poderia ser vista "na constituição do tipo brasileiro, na formação moral, nos usos e costumes, e até na linguagem".

As crendices, as superstições dos pretos, com sua afetividade, refletiram-se na formação de nossa gente que deles herdou "uma certa negligencia criola, uma resignação heroica para suportar a miséria, uma concepção um pouco fatalista e quiçá leviana da vida, sem grandes preocupações do futuro, o hábito do trabalho sem amor, mas também sem revolta, e, enfim, a melancolia impressa mais na música e na poesia do que no estado de alma habitual do povo". (SILVA, 1943, p. 102-103).

A conjunção adversativa "mas" serve para reforçar a tese de que, apesar das más heranças herdadas dos negros, a passividade é o elemento qualificativo. Ou seja, se não há resistência não há lugar para narrar os quilombos e revoltas.

Para o autor os castigos infligidos aos escravos referiam-se aos "casos de delitos de assassínio ou outros de notável gravidade". Em geral "as leis vigentes" e a "índole benévola da maioria dos senhores, inspirados pela religião", suavizavam o cativeiro.

Joaquim Silva diferencia "raça" e "etnia". Dizia não haver, na Europa ou América, povos "dum só tipo comum”, uma só raça, não há uma raça francesa, espanhola, inglesa ou brasileira, mas "povos ou etnias". O autor previa o embranquecimento da população como consequência da "situação estacionária da raça negra e redução do fator indígena”.

\section{O POVO NOS LIVROS DIDÁTICOS ANALISADOS}

Em Lições de História do Brasil Joaquim Manuel de Macedo assinalava que a formação do povo não se referia à questão racial, mas à formação do Estado-Nação imperial. Para ele, progresso e civilização tinham suas fontes nas monarquias, dinastias e Providência Divina. No entanto, conforme Mattos (2000, p. 98), a evidência de alguns temas históricos em Lições "cumpria o papel de pôr em destaque três momentos significativos numa trajetória que tinha o seu ponto de chegada no Império consolidado" [...] "a tematização dos indígenas permitia destacar a ausência de História, de um sentido somente adquirido com a chegada do descobridor português, europeu e cristão". 
Em História do Brasil de João Ribeiro há uma discussão mais aberta sobre a questão no capítulo "As três raças. A sociedade". Amparando-se em pressupostos deterministas, darwinistas e evolucionistas, João Ribeiro predizia a miscigenação como maléfica e em pouco tempo os colonos conheceriam o perigo, enfraquecendo-se e corrompendo-se. Mais além, predizia o advento de uma "raça nacional mameluca" como fator de homogeneização do povo-nação.

Em História do Brasil para o ensino secundário Rocha Pombo ao reconhecer as três raças como formadoras do povo, descreve a mescla como "amálgama dos elementos mais degradados das três raças". O autor valorizava os indígenas e suas relações com os portugueses, isso por haverem contribuído para o domínio do território. $\mathrm{O}$ indígena seria um agente da colonização, assim como João Ribeiro também dissera. Sobre o negro, Rocha Pombo menciona as manifestações em busca de liberdade e a Lei Áurea como desfecho de uma crise prolongada.

Apesar de figurar nos livros didáticos enquanto sinônimo de "pré-história" ou "ausência de história", o indígena brasileiro já constava nas narrativas didáticas, por vezes, representado como herdeiro do povo Inca e agente da formação do território.

Já a figuração do negro africano como elemento constitutivo do povo tardaria um pouco mais, mais exatamente depois da Abolição, quando se postulou a integração do ex-escravo à ordem nacional, portanto, com direitos de cidadania. É a partir de então que a "teoria da miscigenação" assume conotação positiva entre os autores didáticos. Tal como von Martius fizera outrora, principiou-se a valorizar a mestiçagem. Todavia, assinalemos, tal valorização será feita gradualmente.

Uma narrativa com tal característica consta em Rocha Pombo. Com efeito, entre os autores aqui analisados, foi ele quem fez constar um capítulo intitulado "Protestos da raça negra. Palmares".

Nos títulos de Jonathas Serrano a ênfase é mais visível. Com efeito, em História do Brasil consta o capítulo "O elemento africano" no qual ressalta a influência na formação do povo brasileiro. Em Epitome da História do Brasil, por sua vez, elaborou o capítulo "O elemento negro".

A valorização integral da miscigenação nas narrativas didáticas aconteceria nos títulos de Basílio de Magalhães e Joaquim Silva. Note-se, também que o programa de ensino de 1943 estipulava como obrigatório o tema das "três raças" e sua fusão nos seguintes termos: "A formação étnica: 1 . O elemento branco 2. O indígena brasileiro. 3. O negro. 4. A etnia brasileira". 
No campo historiográfico, desde 1920, o modelo racionalista-evolucionista fundado na definição da raça pela biologia e meio-ambiente era debatido. Trata-se, segundo Lima (1989), da transição do modelo historiográfico pautado na herança do Iluminismo francês para o modelo alemão que levava em conta a interferência da cultura. É quando no Brasil é publicado Casa-grande \& senzala de Gilberto Freyre, 1933, um livro tornado "clássico" por inovar os esquemas interpretativos dominantes. Influenciado pelo antropólogo alemão Franz Boas, Gilberto Freyre produziu uma reinterpretação da sociedade brasileira desde o ângulo das relações entre raça, meio e cultura ${ }^{9}$. Desse modo, o autor respaldou e divulgou a teoria da "democracia racial" fundada na miscigenação.

No campo político, na chamada Era Vargas e mais explicitamente no Estado Novo, a teoria da miscigenação tornou-se estratégica na empresa de divulgação da ideologia da união das raças em torno da nação. A “teoria da miscigenação" torna-se integrante da ideologia estadonovista.

Alia-se, aos fatores historiográficos e políticos, o movimento educacional da Escola Nova, que buscava, segundo Monarcha (1989), mobilizar ideológica e politicamente as classes sociais, para superar o atraso nacional e ingressar na modernidade.

Um ponto importante na superação do atraso brasileiro para os chamados escolanovistas seria, conforme Monarcha, a produção cultural: "O movimento da Escola Nova expressa um amplo programa cultural de largo alcance pedagógico, com a finalidade de construir a identidade nacional". (MONARCHA, 1989, p. 19. Grifos do autor).

Haveria, portanto, três esferas da sociedade reelaboradas, a política, a intelectual (historiográfica) e a educacional, de modo a somar forças em prol da construção de uma nação unificada e moderna. A citação a seguir elucida as intenções do movimento e a forma de governo.

O ideário liberal-escolanovista constitui uma estratégia astuciosa de invasão do mundo do trabalho, através de uma via não diretamente repressiva que, entre outras coisas, procurava dissuadir o proletariado urbano de um projeto histórico autônomo, representando-o, no plano das ideias, como agente de um plano histórico previamente traçado. Utilizando-se de uma concepção de história progressista e linear, os sujeitos políticos - as classes sociais - passavam a ser meros agentes da modernidade sob a direção do Estado Administrador. (MONARCHA, 1989, p. 20).

A teoria da miscigenação assumida pela produção historiográfica seria, por assim dizer, chave para a concretização desses objetivos. Essa 
problemática comparece abertamente nos didáticos de Basílio de Magalhães e Joaquim Silva. Entre as heranças acumuladas pela soma das três raças, estaria a passividade, a ausência de revoltas e a conformação para o trabalho.

Por sua vez, as relações em torno do trabalho constam nas narrativas de Jonathas Serrano, Basílio de Magalhães e Joaquim Silva ao se referirem ao povo. Ao explicar os índios como avessos ao trabalho e os negros como aptos ao trabalho, Jonathas Serrano ressaltava o trabalho produtivo como fator essencial nas relações sociais, isso desde os primórdios da colônia.

Quando Basílio de Magalhães afirma que o Estado Novo preocupava-se em tornar o homem brasileiro intelectualmente apto e fisicamente forte para o trabalho e defesa da pátria, ele explicitava a importância do trabalho produtivo.

Por sua vez, Joaquim Silva, ao postular que entre os portugueses degredados haveria gente honesta e trabalhadora, e ao mesmo tempo, postular a falta de amor ao trabalho por parte dos negros, igualmente reforçava a importância do trabalho para a sociedade em formação.

A narrativa predominante nos livros didáticos dos anos 1930-1940 contribuía para a formação de trabalhadores disciplinados, agentes da modernidade desejada desde os tempos de outrora. As relações amenas e harmônicas entre as raças eram exemplificadas com frequência pela história do Brasil colônia, pois, ali estariam as origens da identidade do povo- nação. Contrariamente a interpretação vigente no Brasil na virada do século XIX para o XX, não mais se atribuía a miscigenação a culpa dos males nacionais.

Podemos sintetizar em três momentos as narrativas sobre a formação do povo brasileiro nos livros didáticos de História do Brasil aqui analisados: o primeiro concerne a valorização/reconhecimento do indígena; o segundo, pós-Abolição, a influência do negro na formação do povo e desenvolvimento da economia, todavia, nesse mesmo momento é possível identificar uma desvalorização do índio; o terceiro momento, a valorização da miscigenação entre o branco, o índio e o negro.

Entretanto, lembremo-nos, nos três momentos a teoria do branqueamento e hierarquização das raças se fez presente.

Nos dois momentos iniciais, o embranquecimento da raça não é negado. E mesmo após a valorização da miscigenação na formação da nacionalidade, e, portanto, da constante afirmação de inexistência de preconceitos raciais, o branqueamento não deixou de ser desejado.

De fato, Basílio de Magalhães constatava em sua narrativa o gradual embranquecimento, Joaquim Silva escrevia que a "situação estacionária" da raça negra e a redução numérica do indígena levariam ao embranquecimento como algo natural. 
Contudo, esse enquadramento dos autores e dos livros didáticos em momentos distintos é uma construção narrativa, assim como a estruturação dos textos didáticos, no sentido de que a narrativa não é mais do que uma seleção, que objetiva dar sentido ao desenrolar temporal.

A linearidade que apresentamos pode ser rompida, por exemplo, ao observarmos a influência das referências teóricas alemãs, com a sobreposição do culturalismo, tanto em João Ribeiro como em Gilberto Freyre, com sua teoria da democracia racial pela miscigenação. Os dois utilizaram essa influência em análises distintas, dados os respectivos contextos em que estavam inseridos e seus interesses, mas trata-se de uma mesma corrente analítica em circulação no começo do século XX e que reapareceriam trinta anos mais tarde, rompendo com o modelo explicativo que apregoava a evolução progressiva dos acontecimentos.

Outro fator a ser considerado é a coexistência de momentos distintos em um autor didático. Rocha Pombo, por exemplo, demonstra-se atento à problemática do negro no contexto pós-Abolição, no entanto, há uma postura nítida quanto ao pensamento conservador ou colonialista, o que nos permite associá-lo a Joaquim Manuel de Macedo.

No tocante as inovações historiográficas, elas foram tais em João Ribeiro, não sendo possível assemelhá-lo aos demais autores. Do mesmo modo, as inovações introduzidas por Jonathas Serrano na didática da história não tem precedentes.

Basílio de Magalhães apesar de explicar as "três raças" como formadoras do povo recorre a termos próprios do evolucionismo-biológico: "xantodérmico", "leucodérmico" e "melanodérmico"10. Trata-se de um autor peculiar, pois apesar de escrever e ter sucesso no comércio de didáticos até a década de 1950, seu primeiro livro didático data de 1895, e é do caldo intelectual de final de século XIX que ele produz suas interpretações na década de 1940.

\section{Considerações FINAIS}

É preciso problematizar, quando se refere à concepção de povo nos livros didáticos de História do Brasil, qual é a concepção de cidadania e de história formuladas pelos autores e constantes nos títulos didáticos.

Nos primeiros anos da República, o Brasil vivia uma espécie de crise de identidade, conforme Sandes (2000, p. 17-18), "a imperecível paternidade europeia manifestava-se", afirma o autor, "ora como obstáculo na formulação de um ideário próprio, ora como um desejo de universalidade necessário, para que, no confronto com o outro, a nação se encontrasse - ainda que em sua forma híbrida”. 
A partir de 1930, com o mito da democracia racial, a ideologia vigente nos livros didáticos gira em torno de cidadãos passivos, porém cientes do seu papel histórico na construção do Brasil moderno. Cidadãos viventes em condições sociais radicalmente distintas, mas convivendo de modo pacífico, produtivo e harmonioso e outorgando ao Estado as decisões sobre os futuros rumos da nação. Existia uma plasticidade de democracia racial nos livros didáticos de História do Brasil nesse período que não correspondia à participação efetiva na vida política nacional, não se desdobrava em democratização política, menos ainda, econômico-política.

De outro modo, a democracia racial pós-1930 era um mito que situava o Outro num campo de representações ideológicas e ao mesmo tempo estipulava lugares e funções no corpo social. Esse mito adquire força e visibilidade nos livros didáticos na medida em que o ensino secundário foi deixando de ser socialmente endereçado às elites.

No entanto, antes ou depois de 1930 a cidadania ativa, isto é, a concepção de cidadania que pressupõe não só deveres, mas também o alargamento de direitos sociais e políticos são silenciados nas narrativas didáticas da história do Brasil ao se privilegiar, em conformidade com os programas oficiais de ensino uma história não menos oficial ao se salientar, entre outros, os heróis nacionais.

A concepção de República como governo do povo, gerou a necessidade de formar a população para exercer a cidadania. Aliada à necessidade de formar para a cidadania, era importante construir uma nação, unida e coesa. Notamos que nos títulos analisados o conceito de "povo-nação" vincula-se à figura do Estado tido como elemento crucial da unidade nacional. Para tal, a instrução pública foi ampliada com o objetivo de formar a nação, o povo brasileiro. Como disciplina escolar voltada para esse fim, juntamente com a língua portuguesa e a corografia/geografia do Brasil, estava a História do Brasil.

BRAZILIAN PEOPLE ON THE REPUBLICAN HISTORY DIDACTIC BOOKS: 1889-1950

Abstract: The objective of the present text is to argue the conceptions of people in six didactic books of the History of Brazil produced and used in the school context from 1889 to 1950 . The text is divided in three parts. The first one has initial questions about people and miscegenation; the second one it's about the presentation of Brazilian people conception about each author and their respective didactic books; and on the third part, the conclusions are described. Between the conclusions we 
emphasize on didactic books that analyzed the gradual recognition of the three races like makers of the Brazilian people and the change of the interpretation concerning the miscegenation, that pass from something harmful to something positive and integrant part of the governmental ideology.

Key words: People, Republic, Didactic books of History from Brazil.

\section{NOTAS}

1 Cf. Lafer (1989).

2 Foi a obra mais antiga do autor a que tivemos acesso para analisar os conteúdos iniciais da História do Brasil. Para compor nosso corpus utilizamos junto com este livro História do Brasil - 5a série ginasial (Rio de Janeiro: Francisco Alves, 1942, de acordo com o programa de ensino de 1940).

3 Sobre as teorias raciais e miscigenação, Cf. Schwarcz (1993); sobre a teoria do branqueamento, Skidmore (1989).

4 Título escrito em 1869 e reeditado pela editora Scipione em 198? A terceira edição publicada por essa editora data de 1991.

5 Quando João Ribeiro escreveu História do Brasil, o determinismo biológico justificava a existência de três grandes tipos raciais distintos, os fatos se incumbiam de evidenciar a grandiosidade dos brancos. Cf. Schwarcz (1993).

6 O programa de 1940 estipula que o índio deveria ser tratado no que dizia respeito à "etnografia e etnologia do selvagem". A importância do elemento indígena é sugerida nos programas de 1943 e 1951. O livro didático de Jonathas Serrano apresenta abordagem inovadora posteriormente incorporada ao programa.

7 Crônica do jesuíta André João Antonil em Cultura e opulência do Brasil por suas drogas e minas, Lisboa, 1711, capítulo IX: "Como se há de haver o senhor do engenho com seus escravos".

8 João Ribeiro elabora um capítulo sobre a "escravidão negra", mas com ênfase na escravidão e não no "negro" objetivando explicar a "escravidão negra" e a "escravidão vermelha".

9 Cf. Lima (1989) e Pesavento (2004).

10 Ao afirmar que "a etnia brasileira resultou da fusão de três elementos", Magalhães (1952, p. 49) apresenta o xantodérmico, representado pelo índio, o leucodérmico pelo branco e o melanodérmico pelo negro. De acordo com o Dicionário Aurélio, xantodérmico é relativo à cor amarela da pele, leucodérmico relativo à perda de melanina na pele e, melanodérmico refere-se ao aumento da quantidade de melanina na pele. 
Fontes e RefERÊNCIAS

\section{Fontes}

Antonil, A. J. Cultura e opulência do Brasil. São Paulo: Nacional, 1967.

Macedo, J. M. Lições de História do Brasil. 9. ed. Rio de Janeiro: Garnier, 1907.

Magalhães, B. História do Brasil. Rio de Janeiro: Francisco Alves, 1942.

Martius, K. F. P. von. Como se deve escrever a história do Brasil. Revista Trimensal de História e Geografia ou Jornal do Instituto Histórico e Geográfico Brasileiro, n.24, jan. 1845. Transcrito em: Spix, J.B. \& Martius, K. F. P. v. Viagem pelo Brasil. Belo Horizonte: Itatiaia, p.85-107, 1982.

Ribeiro, J. História do Brasil curso superior. 11. ed. Rio de Janeiro: Francisco Alves, 1928.

Rосна Ромво. J. F. História do Brasil para o ensino secundário. 19. ed. São Paulo: Melhoramentos, 1925.

Romero, S. Mestiçagem e literatura nacional. Gregório de Matos. In: CANDido, A. (Org.) Silvio Romero. Teoria, crítica e história literária. Petrópolis: Vozes, 1978.

Romero, S. O Evolucionismo e o positivismo no Brasil. Rio de Janeiro: Livraria Clássica de Alves, 1894.

Serrano, J. Epítome de História do Brasil. 3. ed. Rio de Janeiro: F. Briguiet \& Cia editores, 1941.

Silva, J. História do Brasil para o terceiro ano ginasial. 8. ed. São Paulo: Nacional, 1943.

\section{Referências}

Bittencourt, C. M. F. Pátria, civilização e trabalho. São Paulo: Loyola, 1990.

Bittencourt, C. M. F. O saber histórico na sala de aula. São Paulo: Contexto, 1998.

Gasparello, A. Construtores de identidades: os compêndios de História do Brasil do Colégio Pedro II (1838-1920). São Paulo, 2002. Tese (Doutorado em Educação). Pontifícia Universidade Católica de São Paulo.

Hansen, P. S. Feições e fisionomia: a história do Brasil de João Ribeiro. Rio de Janeiro: Acess, 2000.

Lafer, C. O significado de República. In. Revista Estudos Históricos. Vol. 2, N. 4, p. 214-224, 1989.

Lima, L. C. A aguarrás do tempo. Estudos sobre narrativa. Rio de Janeiro: Rocco, 1989. 
Mattos, S. R. de. O Brasil em lições. A história como disciplina escolar em Joaquim Manuel de Macedo. Rio de Janeiro: Access, 2000.

Monarcha, C. A reinvenção da cidade e da multidão. Dimensões da modernidade brasileira: a Escola Nova. São Paulo: Cortez, 1989.

Pesavento, S. J. Negritude, mestiçagem e lusitanismo: o Brasil positivo de Gilberto Freire. In: Axt, G. e Schuler, F. (Orgs.) Intérpretes do Brasil. Porto Alegre: Artes e Ofícios, 2004.

RESNIK, L. Tecendo o amanhã (a história do Brasil no ensino secundário: programas e livros didáticos. 1931-1945). Rio de Janeiro, 1992. Dissertação (Mestrado em História) -Universidade Federal Fluminense.

Ribeiro, R. R. Colônia(s) de identidades: discursos sobre a raça nos manuais escolares de História do Brasil. Campinas, 2004. Dissertação (Mestrado em História) - Universidade Estadual de Campinas.

Rodrigues, J. H. História da história do Brasil: a historiografia conservadora. São Paulo: Editora Nacional; Brasília: INL, 1988.

SAndes, N. F. A invenção da Nação, entre a Monarquia e a República. Goiânia: Ed. UFG, 2000.

Schwarcz, L. M. O espetáculo das raças: cientistas, instituições e questão racial no Brasil (1871-1830). São Paulo: Companhia das Letras1993.

Sevcenko, N. L. Literatura como missão: tensões sociais e criação cultural da Primeira República. São Paulo: Brasiliense, 1999.

Skidmore, T. Preto no branco. Raça e nacionalidade no pensamento brasileiro. Rio de Janeiro: Paz e Terra, 1989. 